Gut, 1974, 15, 83-88

\title{
Significance of intravascular coagulation and fibrinolysis in acute hepatic failure
}

\author{
P. HILlENBRAND, ${ }^{1}$ S. P. PARBHOO, ${ }^{2}$ A. JEDRYCHOWSKI, ${ }^{3}$ AND \\ SHEILA SHERLOCK
}

From the Department of Medicine, Royal Free Hospital, London

SUMMARY Twenty-two patients with acute hepatic failure were studied to determine the incidence and magnitude of intravascular coagulation and fibrinolysis and their relation to the severity of bleeding and prognosis. The mean platelet count, Thrombotest, plasminogen activator, and plasminogen were reduced; the reduction in fibrinogen was not statistically significant. Fibrin/ fibrinogen degradation products were only moderately increased. Hepatic fibrin deposition was not extensive, being present in 11 of 22 hepatic sections, more in areas of confluent necrosis than in the sinusoids. The combination of increased fibrin/fibrinogen degradation products with decreased plasminogen activator, plasminogen, and thrombocytopenia is consistent with a diagnosis of intravascular coagulation and secondary local fibrinolysis. However, neither of these processes was severe. Severity of bleeding was related only to plasminogen levels and prognosis only to Thrombotest levels. There was no relation between hepatic histological and haematological findings. Heparin therapy is not indicated in the routine management of acute hepatic failure, as intravascular coagulation is not severe and heparin may itself cause massive bleeding.

Bleeding in patients with acute hepatic failure is mainly due to impaired synthesis of coagulation factors but increased consumption of platelets and these factors may contribute. In addition fibrinolysis, secondary to intravascular coagulation, could worsen the bleeding diathesis if it resulted in a high level of fibrin/fibrinogen degradation products. Recently, heparin therapy has been advocated by Rake, Flute, Shilkin, Lewis, Winch, and Williams (1971), as it has been shown to prolong ${ }^{125}$ I fibrinogen survival and raise plasma fibrinogen levels in patients with hepatocellular failure. These workers have suggested that intravascular coagulation may contribute significantly to liver damage and that early and intensive therapy with heparin and plasma may improve the prognosis.

The aim of our study was to determine the incidence and magnitude of intravascular coagulation and fibrinolysis. The contribution of these disturb-

\footnotetext{
${ }^{1}$ Department of Gastroenterology, The London Hospital, Whitechapel London E1 1BB

'Department of Surgery, Frenchay Hospital, Bristol

'Instytutu Medycyny, Wewnetrznej, ul Kopernika 15, Krakow, Poland

Received for publication 13 November 1973.
}

ances to the bleeding diathesis and their relationship to the prognosis was assessed.

\section{Patients and Controls}

Twenty patients in fulminant acute hepatic failure (Trey and Davidson, 1970) and two patients with mild acute hepatic failure were studied (table I). There were eight male and 14 female patients, aged from 8 to 78 years, with a mean age of 43.2 years. They were usually studied within two days of admission when they had not received blood or plasma transfusions, although parenteral vitamin $\mathrm{K}_{1}$ had been given. The control group (12 males and nine females, aged 21-61 years) consisted of healthy medical and laboratory personnel.

\section{Methods}

Haemoglobin and platelet count were measured on the Coulter counter and the Thrombotest (Owren, 1959) was performed. Plasminogen activator activity was measured by the euglobulin lysis time (Januszko and Dubińska, 1965); the results were expressed as units of activity per millilitre of plasma from the 


\begin{tabular}{|c|c|c|c|c|c|c|c|c|c|}
\hline \multirow{2}{*}{$\begin{array}{l}\text { Patient } \\
\text { No. }\end{array}$} & \multirow{2}{*}{ Diagnosis } & \multirow{2}{*}{$\begin{array}{l}\text { Encephalopathy } \\
\text { (Grade) }\end{array}$} & \multirow{2}{*}{$\begin{array}{l}\text { Bleeding } \\
\text { (Grade) }\end{array}$} & \multirow{2}{*}{$\begin{array}{l}\text { Thrombotest } \\
(\%)\end{array}$} & \multirow{2}{*}{$\begin{array}{l}\text { Platelet } \\
\text { Count } \\
\left.\text { (per } \mathrm{mm}^{\mathrm{s}}\right)\end{array}$} & \multirow{2}{*}{$\begin{array}{l}\text { Plasminogen } \\
\text { Activator } \\
\text { (units } / m l)\end{array}$} & \multirow{2}{*}{$\begin{array}{l}\text { Plasminogen } \\
\text { (units } / \mathrm{ml})\end{array}$} & \multicolumn{2}{|c|}{ Fibrinogen FDP } \\
\hline & & & & & & & & (mg) & $(\mu g / m l)$ \\
\hline 2 & Acute fatty liver of pregnancy & $\mathbf{I}$ & $\mathbf{I}$ & 38 & 125000 & 3.0 & - & - & 15 \\
\hline 3 & Halothane & $\bar{I}$ & II & 10 & 140000 & $1 \cdot 2$ & $<0.5$ & 440 & 10 \\
\hline 4 & Acute fatty liver of pregnancy & I & I & 6 & 144000 & $3 \cdot \overline{8}$ & $<0.5$ & 330 & 107 \\
\hline 5 & Halothane & $\bar{I}$ & 0 & 100 & 318000 & $3 \cdot 9$ & $3 \cdot 3$ & 349 & - \\
\hline 7 & Viral hepatitis & II & $\mathbf{I}$ & 11 & 61000 & $4 \cdot 3$ & $1 \cdot 3$ & 230 & 5 \\
\hline 8 & Viral hepatitis & II & $\overline{\mathbf{I}}$ & 15 & 94000 & $9 \cdot 0$ & $<0.5$ & 163 & 20 \\
\hline 9 & Viral hepatitis & III & $\mathbf{I}$ & 8 & 13000 & $12 \cdot 6$ & $1 \cdot 2$ & - & 20 \\
\hline 10 & Acute fatty liver of pregnancy & III & III & 25 & 115000 & $4 \cdot 0$ & 1.5 & 324 & 20 \\
\hline 11 & Halothane & III & II & 5 & 132000 & - & 1.0 & 120 & - \\
\hline 12 & Acute fatty liver of pregnancy & III & II & 25 & 96000 & $3 \cdot 5$ & $<0.5$ & 290 & 40 \\
\hline 13 & Viral hepatitis & IV & $\mathbf{I}$ & 12 & 95000 & $27 \cdot 0$ & 0.9 & 111 & 10 \\
\hline 14 & Paracetamol & IV & $\mathbf{I}$ & 18 & 256000 & 3.6 & $<0.5$ & 118 & 10 \\
\hline 15 & Paracetamol & IV & $\bar{I}$ & 15 & 183000 & 4.0 & $1 \cdot 0$ & 235 & 10 \\
\hline 17 & Viral hepatitis & IV & II & 8 & 242000 & $3 \cdot 5$ & 0.6 & 130 & 10 \\
\hline 18 & Paracetamol & IV & II & 19 & 115000 & $<1.0$ & 0.8 & 560 & 20 \\
\hline 19 & Halothane & IV & II & 18 & 55000 & $3 \cdot 3$ & - & - & 20 \\
\hline 20 & Viral hepatitis & v & II & 15 & 225000 & $11 \cdot 6$ & 0.7 & 211 & - \\
\hline 21 & Halothane & $\mathbf{V}$ & I & 5 & - & $3 \cdot 7$ & $3 \cdot 0$ & 350 & 40 \\
\hline 22 & Halothane & $\mathbf{V}$ & II & $<5$ & 180000 & $<1.0$ & $<0.5$ & 155 & 20 \\
\hline
\end{tabular}

Table I Clinical and haematological findings

FDP $=$ Fibrin/fibrinogen degradation products.

formula $\frac{1300}{t}$ of Januszko and Dubinska (1965),

where $t$ is the lysis time in minutes. Plasminogen was measured by a caseinolytic assay (Alkjaersig, Fletcher, and Sherry, 1959) and fibrinogen by a thrombin clotting method (Quick, 1959). Fibrin/ fibrinogen degradation products were assayed on microtitre plates, using Burroughs Wellcome reagents, by a modification of the tanned red cell haemagglutination inhibition assay described by Das, Allan, Woodfield, and Cash (1967). Needle specimens of liver were obtained in all patients, either during recovery, when coagulation studies were satisfactory, or within 15 minutes of death (table II). The liver sections were stained with MartiusScarlet-Blue (Lendrum, Fraser, and Slidders, 1962) in order to detect the sites of fibrin deposition.

The severity of hepatic failure at the time of the study was assessed by the grade of encephalopathy, by severity of bleeding, and by the Thrombotest level (table I). Patients fell into the following grades of encephalopathy: grade I, confusion; grade II, drowsiness; grade III, stupor; grade IV, coma with response to painful stimuli; grade V, coma with no response to pain. Severity of bleeding was graded from 0-III: grade 0, no bleeding; grade I, petechial haemorrhages, ecchymoses, and slight oozing from venepuncture sites (transfusions not required); grade II, drainage of altered blood from the stomach and bleeding from the aforementioned sites (plasma transfusions usually required); grade III, drainage of fresh blood from the stomach, with extensive bleeding from other sites (blood and plasma transfusions required). Linear regression analysis and the Wilcoxon rank sum test were used to determine the statistical significance of the results (Wilcoxon and Wilcox, 1964). The results were expressed as mean and range, as the distribution was non-Gaussian.

\section{Results}

\section{SEVERITY OF HEPATIC FAILURE}

More than half the patients were in grade III-V encephalopathy at the time of the study. Grade I encephalopathy was seen in five patients, grade II in three, grade III in four, grade IV in seven, and grade V in three patients (table I). Of the five patients with grade I encephalopathy, one subsequently progressed to grade II and four to grade III. Bleeding was present in all save two patients. Grade I bleeding occurred in 10 patients and grade II in nine; only one patient had massive (grade III) bleeding.

Thrombotest levels at the time of the study were below $20 \%$ inall but four patients. One of these had a level of $100 \%$, associated with transient grade I encephalopathy and rapid clinical recovery. Eight patients had levels of $10 \%$ or less despite vitamin $K_{1}$ therapy.

Linear regression analysis showed an inverse relationship between Thrombotest levels and both the grade of encephalopathy and severity of bleeding (fig 1). However, this relationship was not statistically significant, though in the case of encephalopathy it only just failed to attain statistical significance $(r=-0.4047 ; 0.05<P<0.1)$. All 

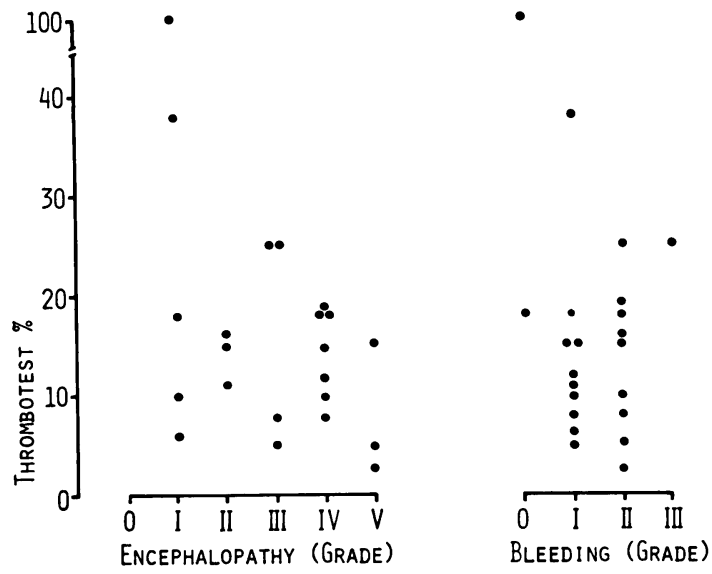

Fig 1 Relation of Thrombotest to encephalopathy and severity of bleeding.

three indices of the severity of hepatic failure were related to the prognosis; the statistical significance of the results was tested by the Wilcoxon rank sum method. Although Thrombotest levels were related to prognosis both on admission and at the time of the study, the relationship was statistically significant $(P<0.05)$ only on admission, usually before vitamin $\mathrm{K}$ administration (fig 2). The relationship between the grade of encephalopathy and prognosis at the time of the study was statistically significant $(P<$ 0.01 ), as was that between severity of bleeding and prognosis $(\mathrm{P}<0.01)$.

- SURVIVED + DIED

\begin{tabular}{|c|c|}
\hline THROMBOTEST & OUTCOME \\
\hline$>25 \%$ & 0 \\
\hline $21-25 \%$ & + \\
\hline $16-20 \%$ & $0++t$ \\
\hline $11-15 \%$ & $0+1+1$ \\
\hline $5-10 \%$ & 0 \\
\hline$<5 \%+1+t$ \\
\hline
\end{tabular}

Fig 2 Relation of Thrombotest to survival on admission $(\mathbf{P}<0.05)$.
PLATELET COUNT AND FIBRINOLYTIC STUDIES The mean platelet count $\left(111000\right.$ per $\mathrm{mm}^{3}$, range $13000-318000$ per $\mathrm{mm}^{3}$ ) was reduced. Eight patients had a normal platelet count and in the remainder the platelet count was but moderately reduced. Only one patient had less than 50000 platelets per $\mathrm{mm}^{3}$.

The results of fibrinolytic studies are shown in figure 3. The shaded area represents the range (mean \pm 2 standard deviations) in 21 normal controls. Mean plasminogen activator activity was decreased (5.72 units $/ \mathrm{ml}$, range $<1.0-27$ units $/ \mathrm{ml}, \mathbf{P}<0.02)$. Only four of the 22 patients had normal and one increased plasminogen activator activity (figure 3 ). The highest levels occurred in patients whose liver failure ran a more prolonged course.

The mean level of fibrin/fibrinogen degradation products was increased $(21.3 \mu \mathrm{g} / \mathrm{ml}$, range $5-107$ $\mu \mathrm{g} / \mathrm{ml}, \mathbf{P}<0.01)$, but this increase was moderate (fig 3). Six patients had levels at the upper limit of the normal range and only one had levels exceeding $100 \mu \mathrm{g} / \mathrm{ml}$. Two of the highest levels occurred in patients with acute fatty liver of pregnancy complicated by preeclampsia and intrauterine death of the foetus.

The mean plasminogen level was significantly decreased $(1.0$ units $/ \mathrm{ml}$, range $<0.5-3.3$ units $/ \mathrm{ml}$, $P<0.01)$ but the decrease in fibrinogen $(272 \mathrm{mg} /$ $100 \mathrm{ml}$, range $111-560 \mathrm{mg} / 100 \mathrm{ml}, \mathrm{P}>0.1)$ did not reach statistical significance. Fibrinogen values were widely scattered; some patients, particularly those with hepatic failure due to drugs or toxins, had high normal or increased levels.

RELATIONSHIP OF HAEMATOLOGICAL FINDINGS TO BLEEDING AND PROGNOSIS

Severity of bleeding was related only to plasminogen levels (fig 4); there was an inverse linear relationship between plasminogen levels and severity of bleeding $(\mathrm{r}=-0.53, \mathrm{P}<0.025), y=1.97-(0.61) x$.

Prognosis was related only to Thrombotest levels (fig 2).

\section{HEPATIC HISTOLOGY}

Hepatic specimens were obtained from all patients (table II) either during convalescence (nine patients) or immediately after death (13 patients). The mean interval between the haematological and histological studies was 8.4 days (range 0-44 days). Some intrasinusoidal fibrin was present in eight of the 22 specimens; most of the fibrin was present in areas of confluent necrosis (fig 5). In five specimens fibrin was also seen in portal or hepatic vein radicles. Two of these specimens were from patients with acute fatty liver of pregnancy and neither biopsy showed hepatic necrosis.

There was no relation between histological findings 

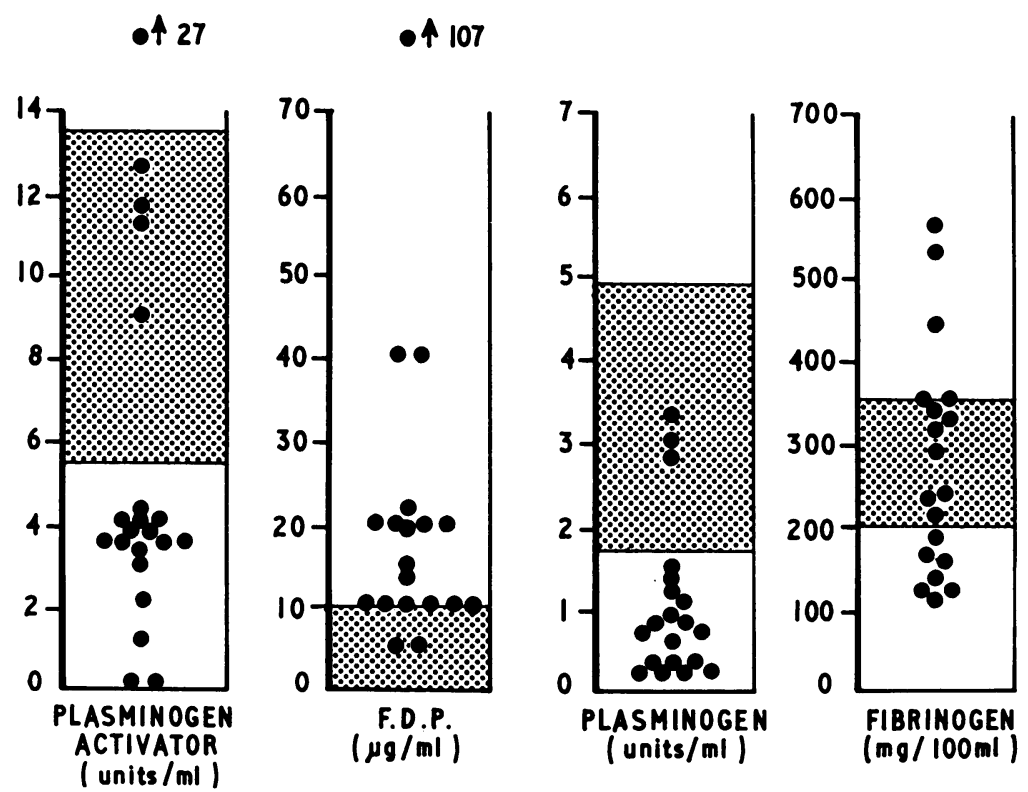

Fig 3 Fibrinolytic studies.

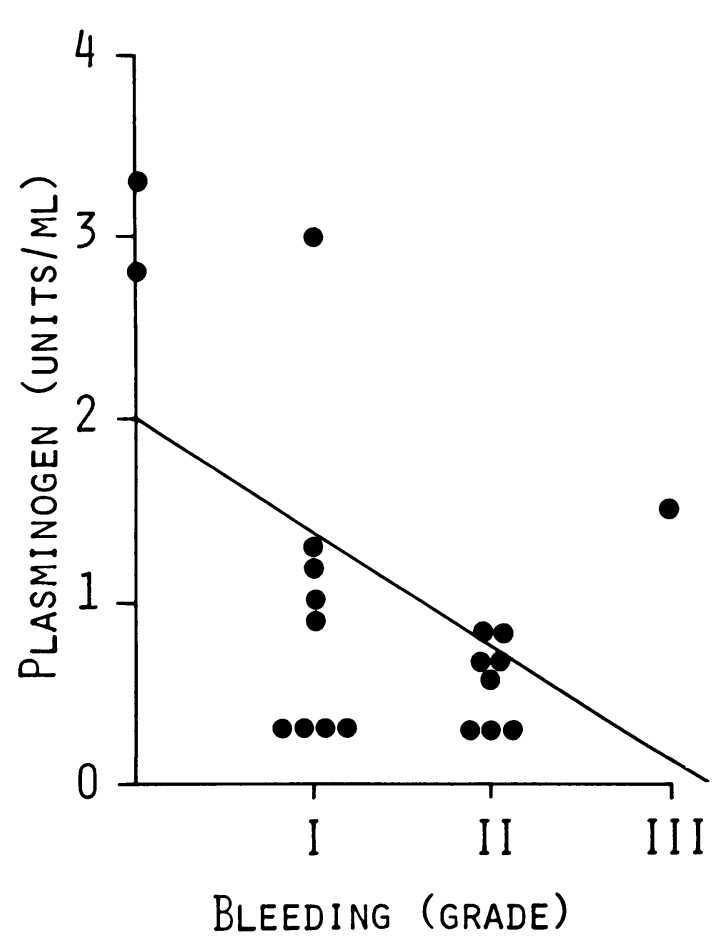

Fig 4 Relation of severity of bleeding to plasminogen level $(r=-0.53, \mathrm{P}<0.025)$. and the indices of coagulation or fibrinolysis. The amount of fibrin deposition was related neither to the severity of bleeding nor to the prognosis.

\section{Discussion}

The haematological findings in most patients were consistent with intravascular coagulation and secondary local fibrinolysis. However, neither of these processes appeared to be severe, as evidenced by the levels of platelets, fibrinogen, and fibrin/fibrinogen degradation products. Liver histology indicated that fibrin deposition was not extensive. The incidence and severity of bleeding at the time of the study were not significantly related to any of the indices of coagulation or fibrinolysis apart from plasminogen levels. Prognosis was related only to the Thrombotest level; this is in keeping with the experience of Cook and Sherlock (1965), who found that the prothrombin ratio was the best prognostic index.

The platelet count was normal or moderately decreased in most patients, which suggests that consumption of platelets was not severe.

Plasminogen activator activity was decreased in most patients and was unrelated to bleeding. Four patients had normal and one increased levels of plasminogen activator. All these patients had a more prolonged illness and in three of them liver histology 


\begin{tabular}{|c|c|c|c|c|c|c|c|c|}
\hline \multirow{3}{*}{$\begin{array}{l}\text { Patient } \\
\text { No. }\end{array}$} & \multirow{3}{*}{$\begin{array}{l}\text { Interval (Days) } \\
\text { between Haematological } \\
\text { and Histological Studies }\end{array}$} & \multirow{2}{*}{\multicolumn{2}{|c|}{$\begin{array}{l}\text { Encephalopathy Grade } \\
\text { at time of }\end{array}$}} & \multicolumn{3}{|c|}{ Site of Fibrin Deposition } & \multirow{3}{*}{$\begin{array}{l}\text { Degree of } \\
\text { Necrosis }\end{array}$} & \multirow{3}{*}{$\begin{array}{l}\text { Liver } \\
\text { Weight } \\
(g)\end{array}$} \\
\hline & & & & Sinusoids & & Portall & & \\
\hline & & $\begin{array}{l}\text { Haematological } \\
\text { Study }\end{array}$ & $\begin{array}{l}\text { Histological } \\
\text { Study }\end{array}$ & Viable Areas & Necrotic Areas & $\begin{array}{l}\text { Central } \\
\text { Vein }\end{array}$ & & \\
\hline $\begin{array}{r}1 \\
2 \\
3 \\
4 \\
5 \\
6 \\
7 \\
8 \\
9 \\
10 \\
11 \\
12 \\
13 \\
14 \\
15 \\
16 \\
17 \\
18 \\
19 \\
20 \\
21 \\
22\end{array}$ & $\begin{array}{r}6 \\
15 \\
31 \\
10 \\
0 \\
6 \\
1 \\
44 \\
2 \\
2 \\
1 \\
12 \\
1 \\
18 \\
20 \\
9 \\
3 \\
3 \\
2 \\
1 \\
0 \\
6\end{array}$ & $\begin{array}{l}\text { I } \\
\text { I } \\
\text { I } \\
\text { I } \\
\text { I } \\
\text { II } \\
\text { II } \\
\text { II } \\
\text { III } \\
\text { III } \\
\text { III } \\
\text { III } \\
\text { IV } \\
\text { IV } \\
\text { IV } \\
\text { IV } \\
\text { IV } \\
\text { IV } \\
\text { IV } \\
\text { V } \\
\text { V } \\
\text { V }\end{array}$ & $\begin{array}{l}0 \\
0 \\
\text { I } \\
\text { I } \\
0 \\
\text { Died } \\
\text { Died } \\
\text { I } \\
\text { Died } \\
\text { Died } \\
\text { Died } \\
\text { I } \\
\text { Died } \\
\text { 0 } \\
\text { Died } \\
\text { I } \\
\text { Died } \\
\text { Died } \\
\text { Died } \\
\text { Died } \\
\text { Died } \\
\text { Died }\end{array}$ & $\begin{array}{l}+ \\
- \\
\pm \\
- \\
\pm \\
\pm \\
- \\
- \\
\pm \\
- \\
- \\
- \\
- \\
+ \\
- \\
- \\
- \\
- \\
- \\
\overline{ \pm} \\
-\end{array}$ & $\begin{array}{l}- \\
- \\
+ \\
- \\
+ \\
+++ \\
- \\
+++ \\
- \\
- \\
- \\
++ \\
- \\
- \\
- \\
- \\
+++ \\
++\end{array}$ & $\begin{array}{l}- \\
- \\
+ \\
+ \\
- \\
- \\
- \\
- \\
- \\
- \\
+ \\
- \\
+ \\
- \\
- \\
- \\
\pm \\
- \\
- \\
-\end{array}$ & $\begin{array}{l} \pm \\
- \\
+++ \\
- \\
++ \\
+++ \\
+++ \\
+++ \\
++++ \\
- \\
++++ \\
- \\
++++ \\
++ \\
+++ \\
+++ \\
++++ \\
+++ \\
+++ \\
++++ \\
++++ \\
++++\end{array}$ & $\begin{array}{l}- \\
- \\
- \\
\overline{-} \\
\text { No necropsy } \\
700 \\
- \\
940 \\
1475 \\
1345 \\
\overline{1065} \\
- \\
855 \\
- \\
370 \\
1400 \\
\text { No necropsy } \\
660 \\
1825 \\
640\end{array}$ \\
\hline
\end{tabular}

Table II Histological findings

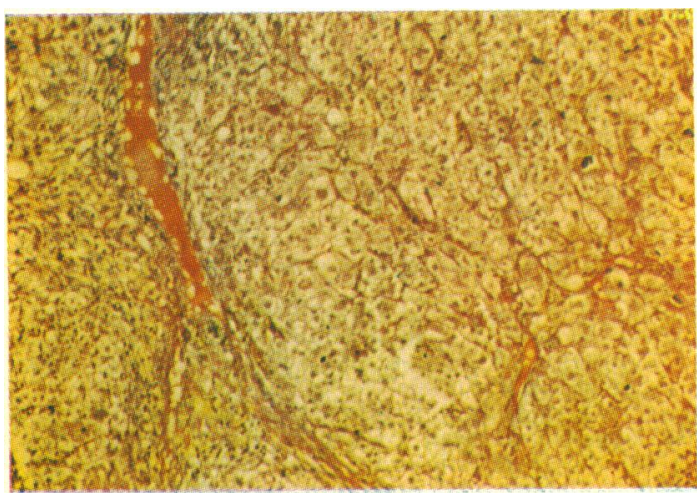

Fig 5 Liver histology (MSB stain $\times 40)$.

The red stain in the portal vein indicates coagulated plasma and that in the sinusoids, fibrin. Deposits of fibrin are also seen in areas of necrosis.

showed nodular regeneration. These patients may have been developing cirrhosis, which is often associated with increased plasminogen activator activity.

Fibrin/fibrinogen degradation products may impair haemostasis by interfering with fibrin polymerization, platelet function, and the thrombinfibrinogen reaction (Larrieu, Marder, and Inceman, 1966). The level of fibrin/fibrinogen degradation products at which this occurs is uncertain, but moderate increases do not appear to cause bleeding. The levels in this study were only moderately in- creased and were unrelated to the severity of bleeding. The highest levels occurred in patients with acute fatty liver of pregnancy complicated by preeclampsia and intrauterine death of the foetus. The two latter conditions are associated with increased levels of fibrin/fibrinogen degradation products, which are attributed to increased local fibrinolysis following intravascular coagulation (Bonnar, Davidson, Pidgeon, McNicol, and Douglas, 1969).

Plasminogen levels were decreased, probably owing to consumption of plasminogen both by increased fibrin deposition and by local fibrinolysis. The low plasminogen levels may have been caused by uptake of plasminogen in areas of hepatic fibrin deposition and might thus have been unrelated to intravascular coagulation. Decreased plasminogen synthesis could be a contributory factor but there is no definite evidence that plasminogen is synthesized by the liver. Barnhart and Riddle (1963) found high concentrations of plasminogen in the eosinophil leucocytes.

Our findings of decreased plasminogen activator activity and plasminogen with increased levels of fibrin/fibrinogen products are similar to those of Rake et al (1970). However, the mechanism underlying the apparently conflicting findings of decreased plasminogen activator activity with decreased plasminogen and increased fibrin/fibrinogen degradation products is uncertain. Johnson and Merskey (1966) have postulated that such findings could result from the formation of local fibrin deposits, with adsorption of plasminogen 
activator, plasminogen, and plasmin on the fibrin clot, followed by lysis of the clot.

The mean fibrinogen level was not significantly decreased, which suggests that consumption of fibrinogen was not severe. Alternatively, a rapid rate of consumption could have been balanced by increased synthesis or release of fibrinogen.

Popper and Franklin (1948) found intrasinusoidal thrombi in toxic hepatic necrosis. In the present study, there were fibrin deposits in 11 of 22 liver biopsy specimens. The relationship between hepatic intravascular coagulation and necrosis is unclear. While most of the fibrin occurred in areas of confluent necrosis it was difficult to establish the exact site of fibrin deposition. Intrahepatic fibrin deposition is seen in cases of disseminated intravascular coagulation without evidence of hepatic necrosis (Whitehead, 1972). In this connexion, it is noteworthy that some of the most prominent intravascular fibrin deposition occurred in two patients with acute fatty liver of pregnancy, neither of whom had hepatic necrosis. The absence of fibrin from the remaining 11 specimens could be due to sampling error. Alternatively, removal of fibrin may have been more complete in these patients than in the others. Lysis of fibrin deposits may occur very rapidly, as shown by the results of thrombin infusions in rats (Margaretten, Csavossy, and McKay, 1967). There was no relation between the histological findings and the indices of coagulation or fibrinolysis; this may be due in part to the variable interval between haematological and histological studies.

Though correction of the coagulation disturbance may be facilitated by combining heparin therapy with plasma infusions (Rake et al, 1971), there is no firm evidence that this regime improves the prognosis. What is clear is that heparin therapy has its dangers. Guillin, Rueff, and Ménaché (1972) treated seven patients with heparin and plasma under strict laboratory control and found that thrombocytopenia was corrected in three patients. However, three patients died of massive gastrointestinal haemorrhage. Clark, Rake, Flute, Borirakchanyavat, and Williams (1972) treated 16 patients, in acute hepatic failure due to paracetamol overdose, with carefully monitored heparin and plasma. Coma developed in 12 patients, nine died and bleeding was a major cause of death in three of these. In the present study, in which heparin was not used, only one of 22 patients died from massive haemorrhage. We therefore feel that heparin therapy may be dangerous and is not indicated in the routine management of acute hepatic failure.

This work was supported by the Royal Free Hospital
Endowment Fund, the Davis Fund, and the Peter Samuel Trust Fund. We thank Dr P. J. Scheuer for help with the interpretation of the liver sections. We are grateful to Miss L. Halliwell for expert technical assistance, to the directors and staff of the Departments of Haematology and Chemical Pathology for their help, and to Nyegaard and Co., a/s, Oslo, for making possible the colour reproduction of figure 5. P. H. was in receipt of a Stanley Thomas Johnson Fellowship and A. J. was a British Council scholar.

Requests for reprints should be sent to Professor Sheila Sherlock.

\section{References}

Alkjaersig, N., Fletcher, A. P., and Sherry, S. (1959). The mechanism of clot dissolution by plasmin. J. clin. Invest., 38, 1086-1095.

Barnhart, M. I., and Riddle, J. M. (1963). Cellular localization of profibrinolysin (plasminogen). Blood, 21, 306-321.

Bonnar, J., Davidson, J. F., Pidgeon, C. F., McNicol, G. P. and Douglas, A. S. (1969). Fibrin degradation products in normal and abnormal pregnancy and parturition. Brit. med.J., 3, 137140.

Clark, R., Rake, M. O., Flute, P. T., Borirakchanyavat, V., and Williams, R. (1972). Paracetamol induced hepatic necrosis. In Proceedings of the Vth Meeting of the International Association for the Study of the Liver, Versailles, p. 27.

Cook, G. C., and Sherlock, S. (1965). Jaundice and its relation to therapeutic agents. Lancet, 1, 175-179.

Das, P. C., Allan, A. G. E., Woodfield, D. G., and Cash, J. D. (1967). Fibrin degradation products in sera of normal subjects. Brit. med. J., 4, 718-720.

Guillin, M. C., Rueff, B., and Ménaché, D. (1972). Coagulation disorders in fulminant viral hepatitis: a therapeutic trial. In Proceedings of the Vth International Meeting for the Study of the Liver, Versailles, p. xii.

Januszko, T., and Dubikska, L. (1965). Estimation of the activator of fibrinolysis by means of the euglobulin test. Acta med. pol., 6,269-276.

Johnson, A. J., and Merskey, C. (1966). Diagnosis of diffuse intravascular clotting: its relation to secondary fibrinolysis and treatment with heparin. Thrombos. Diathes. haemorrh. (Stuttg.), Suppl. 20, 161-172.

Larrieu, M. J., Marder, V. J., and Inceman, S. (1966). Effects of fibrinogen degradation products on platelets and coagulation. Thrombos. Diathes. Haemorrh. (Stuttg.), Suppl. 20, 215-226.

Lendrum, A. C., Fraser, D. S., Slidders, W., and Henderson, R. (1962). Studies on the character and staining of fibrin. J. clin. Path., $15,401-413$.

Margaretten, W., Csavossy, I., and McKay, D. G. (1967). An electron microscopy study of thrombin-induced disseminated intravascular coagulation. Blood, 29, 169-181.

Owren, P. A. (1959). Thrombotest: a new method for controlling anticoagulant therapy. Lancet, 2, 754-758.

Popper, H., and Franklin, M. (1948). Viral versus toxic hepatic necrosis. Arch. Path., 46, 338-376.

Quick, A. J. (1959). Hemorrhagic Diseases, pp. 410-411. Lea and Febiger, Philadelphia.

Rake, M. O., Flute, P. T., Shilkin, K. B., Lewis, M. L., Winch, J., and Williams, R. (1971). Early and intensive therapy of intravascular coagulation in acute liver failure. Lancet, 2, 1215-1218.

Trey, C., and Davidson, C. S. (1970). The management of fulminant hepatic failure. In Progress in Liver Diseases, edited by $\mathbf{H}$. Popper and F. Schaffner, Vol. III pp. 282-297. Grune and Stratton, New York.

Whitehead, R. (1972). Ischaemic enterocolitis: an expression of intravascular coagulation syndrome. Gut, 12, 912-917.

Wilcoxon, F., and Wilcox, R. (1964). Some Rapid Approximate Statistical Procedures. Lederle Laboratories Division, Pearl River, New York. 